\title{
Turmoil in the Capital: British Publication Alarmed the Hamidian Regime
}

\author{
Burhan Çağlar*
}

\begin{abstract}
During the early years of Abdülhamid II's reign, there were several attempts to reinstate ex-Sultan Murad V to the throne. One of these was the initiative of Ali Suâvi, which has come to be known as the Çırağan Incident. Although the Ottoman press had to be very circumspect in reporting Suâvi's attempt and its aftermath, the British newspaper of the Ottoman Empire, The Levant Herald, was instead able to carry the news about the incident for several days by framing its reportage in pro-government terms. The situation changed, however, when a letter from a reader praising Ali Suâvi and supporting the claim of Murad V to the throne was published by the paper and spurred the Sublime Porte into action. Although the authorship of the letter remains unknown, it is doubtful that it was actually written by an average reader of the paper; some sources instead point to Cleanthi Scalieri, the Master of the Prodoos Masonic Lodge. After publication, the proprietor of The Levant Herald, Edgar Whitaker, took refuge in the British Embassy, resulting in the confiscation of the printing house and the remaining copies of the newspaper on the order of the Sublime Porte. Whitaker protested that he had informed the Marshal of the Palace, Said Pasha, regarding the letter's contents, and that he was now the subject of death threats and harassment; Said Pasha responded by denying any knowledge of the matter. The dismissal and exile of Said Pasha brought only further tension. The British Foreign Ministry claiming that the Sublime Porte had acted beyond its jurisdiction according to the capitulations. In the midst of negotiations between the British and Ottoman governments over the transfer of Cyprus, the furor over the letter and the newspaper provoked major discussion in the European press, and caused negative public reaction in Britain towards the actions of the Ottoman government. This article focuses on the anonymous letter published
\end{abstract}

* Research Assistant, Sakarya University, Faculty of Arts and Sciences, Department of History, Sakarya/TURKEY, burhancaglar@sakarya.edu.tr ORCID: 0000-0001-5032-516X

DOI: 10.37879/belleten.2021.133

Application date of article: 21.12.2019 - Approval date of article: 16.11.2020

Belleten, Nisan 2021, Cilt: 85/Say1: 302; 133-153 
in The Levant Herald, and examines the course of these developments primarily through their representation in the British press.

Keywords: The Levant Herald, Said Pasha, Ali Suavi, Edgar Whitaker, Cleanthi Scalieri, Abdülhamid II, Britain

\section{Payitahtta Çalkantı: Hamidiye Rejimini Telaşa Düşüren İngiliz Neşriyatı}

\section{$\ddot{\mathbf{O}}_{\mathbf{z}}$}

II. Abdülhamid'in saltanatının ilk yıllarında sâbık Sultan Murad'ı tekrar tahta geçirmek için bazı teşebbüsler oldu. Bunlardan biri de Çırağan Vakası (1878) olarak bilinen Ali Suâvi'nin tertip ettiği girişimdir. Osmanlı basınında dar bir çerçevede yer bulan olayı İstanbul'da neşredilen İngiliz gazetesi Levant Herald'ın günlerce haber yapması dikkat çekidir. Hükümetin dili ile Çırağan Vakasını sayfalarına taşıyan gazetenin, konu hakkında yayınladığı bir okuyucu mektubu Bâbıâli’yi harekete geçirir. Ali Suâvi'den övgü ile bahseden, V. Murad'ın saltanatının gasp edildiğini ifade eden mektubun kim tarafından kaleme alındığı muammadır. Yayının gerçekte bir okuyucu mektubu olduğuna kimse ikna olmadığı gibi bazı kaynaklar Prodoos (Terakki) Mason Locası Üstad-ı Âzamı Cleanthi Scalieri'yi işaret etmektedir. Levant Herald'ın Bâbıâli'nin emriyle mühürlenerek matbaasına el konması ve nüshalarının toplatılması ile sonuçlanan yayının ardından gazetenin sahibi Edgar Whitaker İngiliz sefaretine sığınır. Whitaker mektubu yayınlaması için ölüm tehdidi aldığını, durumdan Mabeyn Müşiri İngiliz Said Paşa'yı haberdar ettiğini iddia etmektedir. Said Paşa ise padişahın bu konudaki sualine bilgisi olmadığı yönünde cevap verecektir. Paşa azledilerek merkezden uzaklaştırılırken gelişmeler İngiliz hariciyesi ile Bâbıâli arasında gerginlik meydana getirdi. Zira İngiltere adli kapitülasyonlara istinaden Bâbıâli'nin yetkisi dışında hareket ettiğini iddia etmekteydi. Avrupa basınında geniş yankı bulan olay İngiliz kamuoyunda Osmanlı hükümeti aleyhinde sert tepkiler doğurdu. Öte yandan tüm yaşananlar Kıbrıs'ın İngiltere'ye geçici olarak terki müzakerelerinin yürütüldüğü günlere tesadüf ediyordu. Bu çalışma Levant Herald gazetesinde V. Murad ve Ali Suâvi lehine neşredilen mektuba odaklanmakta ve ağırlıklı olarak İngiliz basınında çıkan haberler üzerinden gelişmeleri incelemektedir.

Anahtar Kelimeler: Levant Herald, İngiliz Said Paşa, Ali Suâvi, Edgar Whitaker, Cleanthi Scalieri, II. Abdülhamid, İngiltere 


\section{Introduction}

Abdülhamid II's long reign is the only period in late Ottoman history to be known by the name of its sultan: the "Hamidian" era. Attempts in the early phase of Abdülhamid II's reign to restore his predecessor Murad V to the throne, including that of Ali Suâvi in particular, had an important effect on the conceptualization of the Hamidian regime. The era's tumultuous beginnings were highly influential with regard to the development of Abdülhamid's attitudes, as well as the intellectual, administrative, and political history of the Ottoman Empire in general. In this respect, a number of factors, including the period between the outbreak of the Russo-Ottoman war and, ultimately, the associated peace, Ali Suâvi's failed uprising and an incriminating letter associated with this event published by The Levant Herald, played major roles and marked a turning point in the regime. Accordingly, this period deserves to be studied in much greater detail. Drawing on archival documents and various studies, this article will deal with the letter published in The Levant Herald by situating it within the context of historical conditions. Although important research has been done on the Ali Suavi event - also known as the "Çırağan Incident" - that took place during the earlyHamidian period, surprisingly little has been mentioned about the "seditious" letter published by The Levant Herald. Even more surprising is the lack of research about this extraordinary letter, on the basis of the Anglo-French newspapers in the Ottoman Empire during its later period, nor has there been any study based on the foreign language press of the time. The purpose of this article is to make a contribution to filling these gaps.

\section{Attempts to Restore the Ex-Sultan to the Throne}

During the initial period of Abdülhamid II's (1876-1909) long reign, the main target of opposition groups, known as the Young Ottomans, was to reinstate the sultan's predecessor, Murad V, who had been declared insane and deposed after a 93-day reign ${ }^{1}$. Abdülhamid's accession to the throne had been conditional, based on promulgating a constitution and establishing a legislative assembly. However, he managed to extinguish all opposition coming from the higher echelons of his administration, suspended the constitution, prorogued the assembly, and returned to an absolute regime. The representatives of the early opposition groups became small groups relatively unconnected to power.

1 M. Şükrü Hanioğlu, The Toung Turks in Opposition, Oxford University Press, New York, 1995, pp. 34-36. 
In early December 1876, there was an attempt made to abduct Sultan Murad from Çırağan Palace where he was confined. The purpose was to remove the ex-Sultan from Constantinople and demonstrate to the public his fine mental condition in the hope that it would gain support for his return to the throne. Nevertheless, the plan was foiled, and arrests were made. The collaborators in this incident were never ultimately revealed ${ }^{2}$.

On May 20, 1878, approximately two years after the ex-sultan's deposition, another sensational event occurred: a riot broke out in front of the Ģırağan Palace. The leader of the riot was Ali Suâvi, the previous director of the Imperial College of Galatasaray and one of the former Young Ottomans. He was accompanied by a group of Muslim refugees from the Balkans whose key frustration was the disastrous conduct of the army and the losses resulting from the Russo-Ottoman war of 1877-1878 in which people implicated Abdülhamid II, and thus supported the return of Murad V to the throne. Although the objective of this attack was the release of Murad $\mathrm{V}$ and his reinstatement to the throne, the affair ended in a fiasco in just under an hour. Ali Suâvi and some forty or fifty of his followers were killed by the Imperial troops, and those who survived were arrested and brought to trial. Suâvi's wife, Marie, burned all her husband's paperwork and fled to London the same night ${ }^{3}$.

This notorious incident went down in history as the "Raid of Çırağan" or the "Çırağan Incident," and it resulted in dismissals and sentences of internal exile for a number of statesmen and high-ranking bureaucrats ${ }^{4}$. The Marshal of the Palace, Said Pasha, nicknamed the "Ingiliz" (the Englishman), who had earlier

2 İsmail Hakkı Uzunçarşıll, "Beşinci Murad'ı Avrupa'ya Kaçırma Teşebbüsü", Belleten, X/37 (1946), pp. 195-209; İsmail Hakkı Uzunçarsılı, "Beşinci Murad ile Oğlu Selahaddin Efendiyi Kaçırmak İçin Kadın Kıyafetinde Çırağana Girmek İsteyen Şahıslar”, Belleten, VIII/32 (1944), pp. 589-597.

3 Aaron S. Johnson, A Revolutionary Young Ottoman: Ali Suavi (1839-1878), Unpublished Ph.D. dissertation, McGill University Institute of Islamic Studies, Montreal 2012, pp. 61-62; Ingiliz Said Paşa ve Günliü̆̈̈ (furnal), ed. Burhan Çağlar, Arı Sanat Yayınevi, İstanbul 2010, pp. 141-142. Being Marshal of the Palace, Said Pasha began to keep dairies entitled "Jurnal." These manuscripts are 7 volumes in total and consist of the pasha's political and personal experiences, as well as his observations between 1876 and 1896. Facsimile copies of the first and second volumes can be found in Koç University library, Nesteren-Fuat Bayramoğlu collection, or ISAM library in Istanbul, call numbers: 128495 (vol. 1) and 128496 (vol. 2).

4 Johnson, ibid, pp. 61-62.; Bernard Lewis, The of Emergence Modern Turkey, Oxford University Press, London 1968, pp. 176-177. 
introduced Ali Suâvi to the Sultan, was one of these prominent dignitaries who was blacklisted ${ }^{5}$. Although the investigative reports of the incident in the Ottoman archives imply that the British Ambassador Sir Layard and his secretary, as well as freemasons, were behind Ali Suâvi, this kind of relationship could never be proven $^{6}$. The incident marked the beginning of the sultan's tight hold on the administration of the Ottoman Empire. The deposed Sultan Murad V and his family were subsequently held under house arrest in the Malta Pavilion, on the top of the hill above the Çırağan Palace ${ }^{7}$. Receiving the news from agents, The New Zealand Herald reported the affair thusly: "...Every attempt is made up to hush the matter up, though the conspiracy and the fire at the Sublime Porte together have produced great alarm in government circles. One of the immediate effects has been that the sultan has revived the Grand Viziership in favour of Rushdi Pasha, and replaced Mahmud Damad Pasha at the War Office, but both have since been superseded by other puppets" ${ }^{\prime}$.

In the meantime, the Sublime Porte was in the process of determining who the Ottoman delegates would be to the upcoming Congress of Berlin, which was to be convened to revise the controversial terms of the Treaty of San Stefano, signed in the aftermath of the Ottoman Empire's defeat by Russia on March 3, 1878. Alarmed by the dissection of the Ottoman Empire and by the spectre of Russian hegemony in eastern Anatolia, as well as the possibility of Russian movement across Mesopotamia towards the Persian Gulf and beyond to India, Britain was intent on securing its own strategic interests before the Congress of Berlin began. Therefore, the decision was made, for military purposes, to acquire the island of Cyprus in the eastern Mediterranean, from which Britain could oversee the smooth flow of navigation through the Suez Canal and prevent any future Russian

5 Mahmud Celâleddîn, Mirât-ı Hakikât, Matbaa-i Osmaniye, Dersaadet 1327, vol. III, pp. 138-140.

6 T. C. Cumhurbaşkanlığı, Devlet Arşivleri Başkanlığı, Osmanlı Arşivi (Turkish Presidency State Archives of the Republic of Turkey, Department of Ottoman Archives, İstanbul) (Thereafter BOA.) Y.EE. 79/60, August 27, 1878; Y.EE. 14/7, May 26, 1878; BOA. Y.PRK.AZJ. 2/64, January 30, 1879.

7 İ. Hakkı Uzunçarşıll, "Ali Suâvi ve Çırağan Vak'ası”, Belleten, VIII/29 (1944), pp. 77-78.

8 "The Suez Mail", The New Zealand Herald, July 24, 1878, p. 3.

9 Ali Fuat Türkgeldi, Mesâil-i Mühimme-i Siyâsiyye, vol. 3, ed. Bekir Sıtkı Baykal, Türk Tarih Kurumu Basımevi, Ankara 1957, pp. 1-5; Talha Niyazi Karaca, Büyük Oyun: Ingiltere Başbakanı Gladstone’un Osmanli’y Yikma Planı, Timaş Yayınları, İstanbul 2011, pp. 162-163. 
incursions ${ }^{10}$. In order to achieve this objective, a secret convention was imposed by Britain upon the sultan, entailing that Britain would ostensibly occupy and administer the island of Cyprus for a temporary, but otherwise unspecified, period of time in the name of the Sultan in exchange for the guarantee of the safety of the Asiatic part of the Empire against Russian encroachment and the support of the Ottomans during the Berlin Congress ${ }^{11}$. The Cyprus convention was submitted by Layard, the British Ambassador to Constantinople, to the Sultan via Ingiliz Said Pasha, who had already been persuaded of its advantages, and who soon became the aide-de-camp of the Sultan during the secret negotiations ${ }^{12}$.

Following the Çırağan Incident, the media were put under strict censorship, and almost nothing was allowed to be said of the matter in the Turkish newspapers. Therefore, news about the incident in Constantinople only appeared in any detail only in The Levant Herald, an English-language press published in Constantinople ${ }^{13}$. In accordance with the then-current political conjuncture, The Levant Herald accused Ali Suâvi of being the provocateur of the rebellion and identified him as a seditious, mean-spirited, and factious intriguer, whose perfidious activity had been targeted against the Ottoman nation and the state. Moreover, the news article made explicit reference to the "desperate" health condition of Murad V, and his mental illness was emphasized. Correspondingly, the legitimacy of his dethronement was promoted ${ }^{14}$.

The editor of The Levant Herald, Edgar Whitaker, was an author who focused on a wide range of political subjects, including Ottoman-Russian relations, 'the Eastern Question,' the Bulgarian issue, and tensions in the Balkans. He had recently observed the Russo-Ottoman War as a war correspondent and had travelled

10 Barbara Jelavich, "Great Britain and the Russian Acquisition of Batum, 1878-1886", The Slavonic and East European Review, 48/110 (1970), pp. 47-51.

11 Türkgeldi, ibid, p. 173; Enver Ziya Karal, Osmanh Tarihi, Vol. 9, Türk Tarih Kurumu Basımevi, Ankara 1988, pp. 9-10.

12 M. Celaleddin, ibid, pp. 507-508; İngiliz Said Paşa, pp. 37-39; BOA. Y.EE. 42/203, April 5, 1878.

13 Uzunçarşılı, "Ali Suâvi", p. 85.

14 "The Affair at Tcheragan", The Levant Herald (Weekly Edition), May 29, 1878, p. 2; "Local \& Provincial News", The Levant Herald (Weekly Edition), May 29, 1878, p. 5; "Mysterious Movement at Thceragan" The Levant Herald (Weekly Edition), May 22, 1878, p. 2. "Conflict in the Palace and Death of Ali Suavi Efendi”, The Levant Herald (Weekly Edition), May 22, 1878, p. 4. 
across the Danube frontlines and toured fortifications as a British news reporter ${ }^{15}$. It should be noted that providing information on the subject of foreign countries on an open platform was a particular phenomenon of the $19^{\text {th }}$ century, and often held to be as valuable as espionage reports in the eyes of certain governments ${ }^{16}$.

Whitaker had strong social connections in the Ottoman capital. Although he was born and raised in Britain, he came to Smyrna at a young age. He married into the Abbotts, a famous Levantine family. He was a piano and violin virtuoso and arranged the establishment of the first musical society in Constantinople, the Orchestral Philharmonic Society. In the following years, he continued his interest in music and took part in the management of an organization called the Société Musicale de Constantinople. He compiled his own compositions, and conducted the orchestra at concerts, invitations and balls organized by the Levantine community ${ }^{17}$. His relationship with the British Embassy was not only cultural, since his newspaper required constant contacts and diplomatic support. Whitaker routinely appealed to the legal mechanisms of the Embassy when punishments were imposed on his newspaper by the Porte, seeking their aid in cancelling or abrogating such penalties. Indeed, decades earlier he had taken charge of the Consulate of Gallipoli, which provided him with valuable experience in navigating these networks ${ }^{18}$. Whitaker was a friend of Said Pasha, who had studied in Britain for many years. The chief actor of the Çırağan Incident, Ali Suâvi, was also a friend of Said Pasha, and indeed Said Pasha had previously recommended him to the palace. Suâvi had been publishing dissenting newspapers in Europe, where he had lived for years and married a British woman; ${ }^{19}$ rumours suggested that

15 "Mr. Edgar Whittaker", The Graphic, November 20, 1886, 535; Burhan Çağlar, Brief History of an English-Language Fournal in the Ottoman Empire: The Levant Herald and Constantinople Messenger (18591878), Unpublished MA. dissertation, University of Toronto Department of Near and Middle Eastern Civilizations, Toronto 2017, pp. 38-39.

16 F. A. K., Yasamee, "Some Notes on British Espionage in The Ottoman Empire, 1878-1908", The Balance of Truth: Essays in Honour of Professor Geoffrey Lewis, ed. Çiğdem Balım-Harding, Colin Imber, Isis Press, İstanbul 2000, pp. 432-433.

17 "Obituary", The Times, August, 25, 1903, p. 4; "Death of Mr. Edgar Whitaker", The Levant Herald and Eastern Express, August 24, 1903, p. 1; "Men and Manners in Constantinople", The Eclectic Magazine of Foreign Literature, Science and Art, December 1885, pp. 743-744.

18 Çağlar, Brief History of an English-Language fournal, pp. 73-74.

19 Johnson, ibid, pp. 45, 53-54. 
Said Pasha was also acquainted with Suâvi's wife ${ }^{20}$. In addition, he was the brotherin-law of Fethi Pashazade Damad Mahmud Pasha, who was the most powerful vizier of the time ${ }^{21}$. In the following months, Sultan Abdülhamid accused Mahmud Pasha of organizing the incident behind the scenes ${ }^{22}$. The sultan also said to his entourage that Said pasha was not loyal to him $^{23}$. The British newspapers, which carried the news on their pages, wrote that Mahmud Pasha was known to be close to Ali Suâvi. According to the reportage of these newspapers, Mahmud Pasha (and, therefore, Said Pasha) had a familial friendship with Ali Suâvi ${ }^{24}$. We do not know whether there were, in fact, direct relations between Whitaker and Suâvi. It is likely that their common professional settings, the proximity of their cultural neighbourhoods, and their shared social environments may have presented them to each other in some way. Indeed, the editor of another Levantine newspaper - Jean Pietri, the owner of Courrier d'Orient - supposedly assisted Suâvi's escape to Europe ${ }^{25}$.

In any case, Said Pasha, Ali Suâvi and Edgar Whitaker were in contact with one another. In the eyes of the Sublime Porte, these relations put all of their names under suspicion. Hence, when The Levant Herald reported the Ç1rağan Incident in a clear pro-government tone, this was conceivably with Said Pasha's permission, or even perhaps by his design. Indeed, some rumours later emerged that the two were in close contact regarding a reader's letter related to the incident that was printed in The Levant Herald ${ }^{26}$. In this way, the Ottoman authorities may have supplied the news to The Levant Herald through Said Pasha, and it is for this reason that the censors may have ignored these publications. Since the newspaper was followed in both Europe and the Ottoman lands, it was practical for the Porte to utilize the paper in order to ensure that the government's perspective on the incident would be one disseminated throughout the world. Moreover, among the political

20 M. Celaleddin, ibid, p. 609.

21 Burhan Çağlar, “Zindandan Gelen Sada: Fethipaşazade Mahmud Paşa'nın Taif Mektupları”, Osmanli'da Yönetim ve Savaş, ed., Yaşar Ertaş, Haşim Şahin, Hacer Kılıçaslan, Mahya Yayınları, İstanbul 2017, pp. 173-174.

22 İbnülemin Mahmut Kemal İnal, Son Sadrazamlar, Vol. I, Dergâh Yayınları, İstanbul 1982, p. 778.

23 İngiliz Said Paşa, p. 39.

24 "The Riot at Constantinople", The Times, May 27, 1878, p. 5; "Summary of This Morning's News", The Pall Mall Gazette, May 27, 1878, p. 6; "An Abortive Conspiracy", The Standard, May 28, 1878, p. 5; "The Abortive Revolution", The Western Times, May 28, 1878, p. 8.

25 Hüseyin Çelik, Ali Suâvi ve Dönemi, İletişim Yayınları, İstanbul 1994, p. 90.

26 BOA. Y.EE. 42/217, Jun 11, 1878. 
and cultural circles addressed by The Levant Herald, many were sympathetic to the ex-Sultan Murad V. The paper thus also represented an opportunity to reach this audience, to emphasize the illness and mental instability of the ex-sultan, and to argue that his rule could not possibly be legitimate. Furthermore, with The Levant Herald widely perceived as the media organ of the British Embassy, the dissemination of the perspective of the Porte in the paper would not leave any doubts that the current Ottoman rulership and the reign was seen as legitimate by Britain ${ }^{27}$.

Upon the hearing of the allegations that the ex-sultan was insane, however, much of the foreign press resumed publishing inflammatory articles and news pieces describing how Murad $\mathrm{V}$ had in fact regained full possession of his mental faculties ${ }^{28}$. By distributing this opinion, it was in effect implying the legality of Ali Suâvi's actions, and the reinstatement of Murad V to the throne. The grounds for this claim was the belief that the ex-sultan Murad had recovered his reason and that Abdülhamid II was therefore a usurper, which meant he should return the throne to its rightful owner ${ }^{29}$. In one case, the newspaper Correspondence de l'Est announced that it would issue a brochure defining Murad V to be perfectly healthy, and exhibiting no sign of mental derangement; thus, it was his right that he should reclaim the throne. Subsequently, when the same newspaper's reporter arrived in Constantinople, he promised not to publish the brochure in exchange for money and favours ${ }^{30}$.

\section{Mysterious Letter in the Newspaper}

A few days later, the editor of The Levant Herald, Edgar Whitaker, received an extraordinary letter from an anonymous reader asking for it to be published in

27 Çağlar, Brief History of an English-Language Journal, pp. 29-30.

28 "The Riot at Constantinople", The Times, February 13, 1878, p. 5; "The ex-Sultan", The Westport Times, July 31, 1877, p. 4; "The Truth about ex-Sultan Murad", The Bruce Herald, January 31, 1896, p. 6; "Death of ex-Sultan Murad", The Sydney Morning Herald, September 1, 1904, p. 5; The news in the Star regarding Murad's health asserts as "a strong, additional confirmation has been received from Constantinople that ex-Sultan Murad has been great measure recovered. As those who are disconnected with the present regime favor his restoration to power, his recovery considerably complicated the internal situation." "Europe", The Star, July 19, 1877, p. 3.

29 "Turkey and East", Thames Star, January 29, 1877, p. 2; "General News Summary", Grey River Argus, January 29, 1877, p. 2.

30 Kemal H. Karpat, The Politicization of Islam: Reconstructing Identity, State, Faith, and Community in the Late Ottoman State, Oxford University Press, New York 2001, pp. 134-135. 
the newspaper, with an accompanying death threat should the paper refuse to publish $\mathrm{it}^{31}$. The letter, in favour of Murad V, accused the paper of distorting the facts about the Çırağan Incident and denounced the present sultan as a usurper and imprudent ${ }^{32}$.

Whitaker was thereupon directed to consult with his friend, Ingiliz Said Pasha, about the matter, to which Said Pasha responded by shrugging his shoulders and mumbling "you would publish it" 33 . Additionally, according to an espionage report in the Ottoman Archives, the British ambassador, who was hoping for the reinstallation of Murad V to the throne, was aware of the letter and encouraged Whitaker to print $\mathrm{it}^{34}$. Although this kind of espionage report likely contained false information based on hearsay ${ }^{35}$, it is significant in that it demonstrates the public perception of the event with regard to the relationship between The Levant Herald and the British Embassy, and it helps to indicate the then-current public perception of the then current political situation.

On Saturday, June 1, 1878, The Levant Herald published the letter with prefatory editorial remarks, offering to provide the police with the original copy. Nonetheless, the Sublime Porte declared the letter defamatory and seditious; the paper was immediately suppressed, and the police took possession of the printing house. Moreover, an attempt was made to bring Whitaker before a military court, but this was resisted by the British Consul General, Mr. Fawcett, on the grounds that the Capitulations protected a British subject from such a summary method of procedure. Ultimately, he was ordered to leave the country within five days of the declaration; however, he took refuge in the British Embassy in Constantinople and was entertained by Fawcett in his own house for a while ${ }^{36}$. An extract from

31 İ. Hakkı Uzunçarşıll, "Beşinci Sultan Murad'ın Tedavisine ve Ölümüne Ait Rapor ve Mektuplar", Belleten, X/38 (1946), p. 321.

32 "Turkey", The Argus, July 20, 1878, p. 9; "The Grand Vizierate”, The Standard, June 13, 1878, p. 5.

33 Uzunçarşıll, "Beşinci Murad'ın Tedavisine”, p. 321.

34 BOA. Y.EE. 42/217, Jun 11, 1878.

35 Regarding espionage reports see: Mehmet Ali Beyhan, "II. Abdülhamit Döneminde Hafiyye Teşkilatı ve Jurnaller", Ilmi Araştrmalar, 8 (1999), pp. 65-83.

36 "The Press in Turkey", The Daily Newes, June 4, 1878, p. 5; "Summary of This Morning's News", The Pall Mall Gazette, June 4, 1878, p. 6; "The Situation in Turkey", The York Herald, June 11, 1878, p. 6; "Turkey", The Morning Post, June 20, 1878, p. 6; "Uneasiness in Constantinople", The Bristol Mercury and Daily Post, June 11, 1878, p. 8; "Foreign Intelligence", Reynolds's Nerespaper, June 16, 1878, p. 2; "The Turkish Press", The Standard, June 04, 1878, p. 5; "Foreign", The Graphic, June 15, 
The Pall Mall Gazette illustrates the scene, stating: "Mr. Whitaker is at present living with Mr. Fawcett at Therapia (Tarabya), and the house is surrounded by spies and agents of the police in disguise" ${ }^{\prime 37}$. An edition of The Daily News, published in London on June 10, 1878, provides a semi-official and more in-depth description of the event as follows:

On Saturday afternoon, a stupid and seditious letter appeared in The Levant Herald, for which the paper was next day suppressed, and Mr. Whitaker, the editor, was ordered to leave the country within forty-eight hours. He has not, however, yet left. It is understood that Mr. Layard is trying to obtain the revocation of this order. The letter in question, says The Levant Herald, was sent anonymously. The editor professed his readiness to hand it over to the police... The letter is connected in public opinion with Ali Suâvi's attempt. An examination is now going on into that attempt $\mathrm{t}^{38}$.

It is regrettable that the issue of The Levant Herald containing the letter is unavailable at present. Libraries and research centres such as the Ottoman Bank Archives and Research Centre, the İstanbul Metropolitan Municipality's Atatürk Library, National Library of Turkey, the Centre for Research Library, the Library of Congress, and even the British Library, which holds the collection of The Levant Herald, do not hold a copy of this particular issue. Hence, it can probably be deduced that all copies had been confiscated by the police. Nevertheless, the foreign correspondents in Constantinople did not neglect to dispatch this incriminating letter by telegraph to the foreign press, some of which published it in its entirety. The Standard in London and The Argus in Melbourne are two such journals that received the contents of the letter by telegraph, and published it along with The Levant Herald's prefatory editorial notes as follows ${ }^{39}$ :

We have received the following seditious and malicious letter, the original of which is at the disposal of the Minister of Police, should his energetic Excellency deem it worth the trouble of an inquiry:

M. Le Directeur While the Ottoman nation bases all its hopes of salvation on England, and seeks by every possible means to throw off the yoke imposed upon it by a usurper, who, by his ignorance, his imprudence, and

1878, p. 19; "The Situation in Constantinople", Birmingham Daily Post, June 11, 1878, p. 8.

37 "Turkey", The Standard, June 10, 1878, p. 5.

38 "Latest Telegrams", The Daily Neres, June 10, 1878, p. 5.

39 "The Grand Vizierate", The Standard, June 13, 1878, p. 5; "Turkey", The Argus, July 20, 1878, p. 9. 
his boundless ambition, has reduced his country to the verge of destruction; and to replace on the throne him who alone enjoys the national confidence, and who may by his exceptional qualifications, which are recognised throughout Europe, regenerate his country and initiate its advance on the path of progress and liberty, we are astonished to find that the editor of The Levant Herald - a journal much esteemed at Constantinople - instead of conforming to the sentiments of justice and equity which ought to inspire him, instead of conforming to the great principle of publicity of ascertained truths, instead of sympathizing with unmerited misfortune, allows himself, on the contrary, to be misled by false information, and thus becomes the servile organ of the tyranny of those whose interest it is to suppress the truth for their own base purposes. It is surprising to find that a man who is held in general estimation, and who is endowed with good sense, should fall into such a trap, and should stoop to insert in his journal articles so contrary to the evident truth - that he should represent the health of Sultan Mourad as failing and his ultimate complete cure as doubtful, when on the contrary, no one is ignorant that the ex-sultan is in the most perfect enjoyment of all his intellectual faculties. We pray then, M. Le Directeur, in the name of humanity, of justice, of truth, and of your own conscience, to correct all that you have recently written- to show yourself in future superior to such calumnious insinuations, and to become the exponent of the will of a united nation. Thus, you will have the satisfaction of knowing that you are fulfilling the duties of an honest man and of an impartial journalist. In the opposite event we cannot guarantee you against the unfortunate results of such blindness of conscience - By the mouth of the Ottoman nation.

The Standard reveals that the version of the letter that was published in the English language newspapers was a translation. The original was written in French and it appeared only in the French portion of The Levant Herald. In addition, The Argus emphasizes the frequent suppression of The Levant Herald by the Sublime Porte, and criticized Whitaker for inviting suppression once more, since the publication of the letter would foreseeably cause it. Thus, from these journals, we are left with the question: "Why, then, did Whitaker invite suppression by publishing an anonymous letter, which was wholly disapproved by the Porte"40?

\section{Influence of the Publication: Turmoil in the Capital}

Turkish historian İsmail Hakkı Uzunçarşılı asserts that the letter was sent by the grand master of the Prodoos (Terakkî) Masonic Lodge ${ }^{41}$ Cleanthi Scalieri, who

40 "The Grand Vizierate", The Standard, June 13, 1878, p. 5; "Turkey", The Argus, July 20, 1878 , p. 9.

41 The Proodos ("Terakki" in Ottoaman Turkish and "Progress" in Greek) Masonic Lodge was

Belleten, Nisan 2021, Gilt: 85/Say1: 302; 133-153 
had many European connections, and to whom Murad V had smuggled a note stating: "If you do not save me from this place, Malta Pavilion will be my grave"42. Even though the newspapers reported that no-one was satisfied with the idea that the letter published by The Levant Herald had been received from a genuine reader, it nevertheless had an effect on the present sultan, and Murad V was reinstalled in the Çırağan Palace with his entourage ${ }^{43}$. In fact, another attempt was staged a month later, under the leadership of the very same Cleanthi Scalieri, to rescue the ex-sultan from the Çırağan Palace and allow him to escape to Europe. However, this too resulted in failure ${ }^{44}$.

Exposed by the pressure of the defeat and the Çırağan Incident, the letter published by The Levant Herald soon created a political crisis in Constantinople and strained the relationship between the sultan and the Sublime Porte. In the midst of this chaotic atmosphere, the Cyprus convention was signed on June 4, 1878, over the objections of some of the ministers, and under a virtual ultimatum of the British ambassador ${ }^{45}$. Afterwards, the grand vizier was removed, and a government reshuffle took place, something which had already taken place seven

founded in Pera in 1865, as an associate of the French lodge L'Union d'Orient "Grand Orient". The lodge's rituals were conducted in both Turkish and Greek. In 1872, a Constantinople-born Ottoman-Greek, Cleanthi Scalieri became Grand Master of the lodge, and on October 20 of that year Prince Murad was clandestinely inducted into the lodge, sponsored by his chamberlain Seyyid Bey. Murad rose through the ranks in the lodge, which was named Envar-i Şarkiye, "Light of the Orient," with its ritual conducted in Turkish, but the plan was never realized. Scalieri who played a significant role Prince Murad's accession to the throne, had the intention of founding a new Byzantine state that would unite Turks and Greeks under an enlightened Ottoman sultan's sovereignty. Edhem Eldem, 5. Murad'n Oğlu Selahaddin Efendi'nin Evrak ve Yazıları, Vol. I, İş Bankası Kültür Yayınları: İstanbul 2019, pp. 18-21; Hanioğlu, ibid, pp. 34-36; Ahmet Kısa, ibid, p. 10; Abdurrahman Erginsoy, Türkiye'de Masonluğun Doğuşu ve Gelişsmesi, Erciyaş Yayınları, İstanbul 1996, pp. 15-16;

42 İ. Hakkı Uzunçarşılı, "V. Murad'ı Tekrar Padişah Yapmak İsteyen K. Skaliyeri-Aziz Bey Komistesi”, Belleten, VIII/30 (1944), p. 287.

43 Uzunçarşıll, "V. Murad'ı Tekrar Padişah Yapmak İsteyen", p. 288; This was reported as: "Rushdi Pasha, the new Grand Vizier, has informed the ambassadors that the Sultan has ordered the ex-Sultan Murad to be reinstalled in the Tcheragan (Çırağan) Palace, and all persons accused of participating in the Ali Suavi's conspiracy to be set at liberty." "The Eastern Crisis", Lloyd's Weekly Nerespaper, June 2, 1878, p. 2.

44 Uzunçarşlı, "V. Murad'ı Tekrar Padişah”, pp. 287-288; Eldem, ibid, pp. 18-21.

45 Türkgeldi, ibid, p. 102; Mahmud Gelaleddin, ibid, p. 608; İbnülemin Mahmut Kemal İnal, Osmanl Devrinde Son Sadrazamlar 2, Dergah Yayınları, İstanbul 1982, p. 762. 
times in the previous six months. A number of the most prominent dignitaries and palace employees were dismissed ${ }^{46}$.

Edgar Whitaker remained at the house of British Consul General at Tarabya for some time. He was threatened with trial, imprisonment, and expulsion, and the police sought him daily in Constantinople and Pera. After pleading at length, he obtained an interview with Prime Minister Safvet Pasha; he apparently gave a satisfactory explanation and received a pardon. Moreover, he attained permission to bring out a new paper, The Constantinople Messenger, so long as he avoided inopportune remarks. The pardon stipulated that Whitaker would be forced to leave Constantinople for a few weeks, and that his new paper could begin publication after his departure. As his family was in France and he had hoped to see the ongoing exhibition in Paris, he left for France in good spirits ${ }^{47}$. Concerning the situation, The Daily Neres wrote:

The important political part of the question is the claim to have English subjects brought before a Turkish court-marital. Our Consul General has protested against such a claim as one that disregards and defies the express stipulations of our agreement with the Turkish authorities... The Sultan and the Pachas might be as barbarous as they please in their dealings with Turkish subjects, it was clearly impossible that Englishmen could be surrendered to their ignorance, their rapacity and their arbitrary freaks... We have stood between the Turkish government and its responsibilities. We have taught the Porte the baleful lesson that its safety depends not on the loyalty of its people given in return for its justice and liberality... ${ }^{48}$

The first issue of The Constantinople Messenger was published on July 24, 1878, with the same staff and in the same office of The Levant Herald. The daily edition was printed in English and French, whilst the weekly edition was printed only in English.

At this point, it should be remembered that one of the main focal points of the political opposition to the Hamidian regime were the Masonic lodges ${ }^{49}$. If it

46 Ingiliz Said Paşa, pp. 42-44.

47 BOA. I.DH. 784/63727, April 14, 1879; BOA. İ.DH. 986/77806, April 15, 1886; BOA. Y.MTV. 6/71, July 3, 1881; "Turkey", The Argus, August 17, 1878, pp. 4-5; "A Suppressed Newspaper", The Mercury, August 23, 1878, p. 2.

48 "London, Monday, June 10", The Daily Newes, June 10, 1878, p. 4.

49 Hanioğlu, ibid, pp. 36, 40; Ahmet Kısa, Cleanthi Scalieri ve Aziz Bey Komitesi (1876-1878), Unpublished master's thesis, Hacettepe University Institute of Social Sciences, Ankara 2012, pp. $10-17$. 
is true that the letter published in the newspaper was sent, as alleged, from a Masonic lodge, then it is noteworthy that The Levant Herald was their newspaper of choice. This could be taken as another sign that opposition groups were among the audience that The Levant Herald appealed to. At this stage, the newspaper was regarded as a potent vehicle for dissident viewpoints and was taken as the representative for various oppositional groups, ranging from the Young Ottomans to the Masonic lodges. These groups were generally made up of well-educated people from the upper classes who were familiar with European languages. They had many demands in common, such as the removal of censorship, freedom of thought, and other reforms ${ }^{50}$. By providing a platform for these groups, The Levant Herald contributed to the formation of the political opposition to the Hamidian regime during the late Ottoman Empire.

On the other hand, it is noteworthy that the content of the published letter was harshly critical of the newspaper itself. The newspaper must have, in a sense, stirred up feelings of "betrayal" and disappointment in the eyes of politically dissident groups due to its coverage of the Çırağan Incident when it used progovernment language and accused Ali Suâvi, as one of the important figures of the political opposition, of being "seditious," a "factious intriguer," and "meanspirited." Of course, the newspaper could have decided not to publish the letter at all, and the proprietor of the newspaper could very well have taken different precautions against the death threats that came to him with the letter. However, the newspaper found a valuable use for these threats. By publishing the letter, The Levant Herald both displayed its "dissident" credentials to opposition circles and gave everyone a chance to see what kind of pressure and retaliation they faced when they took such a stance.

On the other hand, it should not be forgotten that the British and the Ottoman Empires were establishing a close political relationship during the same time period that the letter appeared in The Levant Herald. A political alliance was in the works in preparation for the Congress of Berlin, and both sides were in negotiations over the Cyprus convention. It is likely that the letter had a significant effect on the Ottoman government and the Sultan himself, as it was staunchly in favour of the deposed Sultan Murad V. The publication of such a letter in a British paper may have been seen as a veiled threat. According to the available data, the convention was a fait accompli and that the Sultan wished to have it reversed

50 Hanioğlu, ibid, pp. 26-27.

Belleten, Nisan 2021, Cilt: 85/Say1: 302; 133-153 
soon after ${ }^{51}$. It is possible that this letter was one of the motivations for the Sultan's cabinet shuffle, which took place soon afterwards, and in which prominent dignitaries were removed from the capital by appointing them to provincial governorships. The resulting tense atmosphere strengthened Britain's hand, and gave it more leverage in its negotiations with the Ottoman Empire. Thus, these political concerns may also have influenced The Levant Herald's decision to publish the letter. These developments destroyed the Ottoman prestige and ended the already fragmented Crimean system, and indeed demolished the last remnants of the informal Ottoman-British alliance ${ }^{52}$.

\section{Conclusion}

Through these developments, the Ottoman authorities experienced the practical reality of how dire diplomatic tensions could break out in case of any direct intervention in those press organs that were subject to the capitulation laws. The newspaper was clearly under the protection of the British authorities, which defended the newspaper staff whenever necessary. In addition, the ability of The Levant Herald to sway European public opinion regarding the Ottoman Empire became increasingly apparent. This situation also revealed how the foreignlanguage press had the potential to cause deterioration in relations between the Empire and European states. It seems that the Ottoman government could not find any option in the end except to resolve the situation on agreeable terms by pardoning the newspaper's proprietor. The government then issued him a new publishing license so that he could print a new newspaper under a new name. However, the incident undoubtedly strengthened Abdülhamid's belief in the necessity of censorship and must have been one of the important turning points marking the beginning of severe repression of the press in the Hamidian era.

51 Gül Tokay, "Anglo-Ottoman Relations and William Gladstone", New Bulgarian University History Department Yearbook, 4 (2009), pp. 326-327.

52 Gül Tokay, ibid, pp. 326-327. 


\section{BIBLIOGRAPHY}

\section{Archival Documents, Journals and Periodicals}

İrade Dahiliye (İ.DH)

Yıldız Esas Evrakı (Y.EE)

Yıldız Mütenevvi Maruzat Evrakı (Y.MTV)

Yıldız Perakende Evrakı Arzuhal Jurnal (Y.PRK. AZJ)

Birmingham Daily Post

Thames Star

Reynolds's Newespaper

The Argus

The Bristol Mercury and Daily Post

The Bruce Herald

The Daily News

The Graphic

The Eclectic Magazine of Foreign Literature

The Grey River Argus

The Levant Herald

The Levant Herald and Eastern Express

The Mercury

The New Zealand Herald

The Pall Mall Gazette

The Standard

The Star

The Sydney Morning Herald

The Times

The Western Times

The Westport Times

The York Herald

\section{Published Sources and Dissertations}

Johnson, Aaron S., A Revolutionary Young Ottoman: Ali Suavi (1839-1878), Unpublished Ph.D. dissertation, McGill University, 2012. 
Kısa, Ahmet, Cleanthi Scalierive Aziz Bey Komitesi (1876-1878), Unpublished master's thesis, Hacettepe University, 2012.

Birinci, Ali, "Osmanlı Devleti'nde Matbuat ve Neşriyat Yasakları Tarihine Medhal", Türkiye Araștrmalan Literatür Dergisi, 7 (2006): 291-349.

Brummett, J. Palmira, Image and Imperialism in the Ottoman Revolutionary Press, 19081911, State University of New York Press, Albany 2000.

Çağlar, Burhan, "Zindandan Gelen Sada: Fethipaşazade Mahmud Paşa'nın Taif Mektupları", Osmanh'da Yönetim ve Savaş, ed., Yaşar Ertaş-Haşim Şahin-Hacer Kıllı̧aslan, Mahya Yayınları, İstanbul 2017, pp. 173-192.

Çağlar, Burhan, Brief History of an English-Language fournal in the Ottoman Empire: The Levant Herald and Constantinople Messenger (1859-1878), Unpublished master's thesis, University of Toronto, 2017.

Çelik, Hüseyin, Ali Suâvi ve Dönemi, İletişim Yayınları, İstanbul 1994.

Eldem, Edhem, 5. Murad'ın Oğlu Selahaddin Efendi’nin Evrak ve Yazlları, Vol. I, İş Bankası Kültür Yayınları, İstanbul 2019.

Yasamee, Feroze A. K., "Some Notes on British Espionage in The Ottoman Empire, 1878-1908", The Balance of Truth: Essays in Honour of Professor Geoffrey Lewis, ed., Çiğgem Balım-Harding, Colin Imber, Isis Press, İstanbul 2000, pp. 431- 442.

Georgeon, François, Sultan Abdiulhamid, tr. Ali Berktay, Homer Kitabevi, İstanbul 2006.

Hanioğlu, M. Şükrü, The Toung Turks in Opposition, Oxford University Press, New York 1995.

İnal, İbnülemin Mahmut Kemal, Osmanh Devrinde Son Sadrazamlar, Vol.1-2, Dergah Yayınları, İstanbul 1982.

İngiliz Said Paşa ve Günlüğü (furnal), ed. Burhan Çağlar, Arı Sanat Yayınevi, İstanbul 2010.

Jelavich, Barbara, "Great Britain and the Russian Acquisition of Batum, 18781886", The Slavonic and East European Review, 48/110 (1970), pp. 44-66.

Karaca, Talha Niyazi, Büyük Oyun: İniltere Başbakanı Gladstone'un Osmanl'y rikma Planı, Timaş Yayınları, İstanbul 2011. 
Karal, Enver Ziya, Osmanlı Tarihi, vol. 9, Türk Tarih Kurumu Basımevi, Ankara 1988.

Karpat, Kemal H., The Politicization of Islam: Reconstructing Identity, State, Faith, and Community in the Late Ottoman State, Oxford University Press, New York 2001.

Lewis, Bernard, The of Emergence Modern Turkey, Oxford University Press, London 1968.

Mahmud Celâleddîn, Mirât-ı Hakikât, Vol. III, Matbaa-i Osmaniye, Dersaadet 1327.

Tokay, Gül, "Anglo-Ottoman Relations and William Gladstone", New Bulgarian University History Department Tearbook, 4 (2009), pp. 318-333.

Türkgeldi, Ali Fuat, Mesâil-i Mühimme-i Siyâsiyye, Vol. 3, ed. Bekir Sıtkı Baykal, Türk Tarih Kurumu Basımevi, Ankara 1957.

Uzunçarşılı, İ. Hakkı, “Ali Suâvi ve Çırağan Vak'ası”, Belleten, VIII/29 (1944), pp. 71-118.

Uzunçarşılı, İ. Hakkı, "Beşinci Murad ile Oğlu Selahaddin Efendiyi Kaçırmak İçin Kadın Kıyafetinde Çırağana Girmek İsteyen Şahıslar”, Belleten, VIII/32 (1944), pp. 589-597.

Uzunçarşılı, İ. Hakkı, "Beşinci Murad'ı Avrupa'ya Kaçırma Teşebbüsü”, Belleten, X/37 (1946), pp. 195-209.

Uzunçarşılı, İ. Hakkı, "Beşinci Sultan Murad'ın Tedavisine ve Ölümüne Ait Rapor ve Mektuplar", Belleten, X/38 (1946), pp. 317-367.

Uzunçarşıll, İ. Hakkı, "V. Murad'ı Tekrar Padişah Yapmak İsteyen K. SkaliyeriAziz Bey Komitesi”, Belleten, VIII/30 (1944), pp. 245-328. 


\section{APPENDICES}

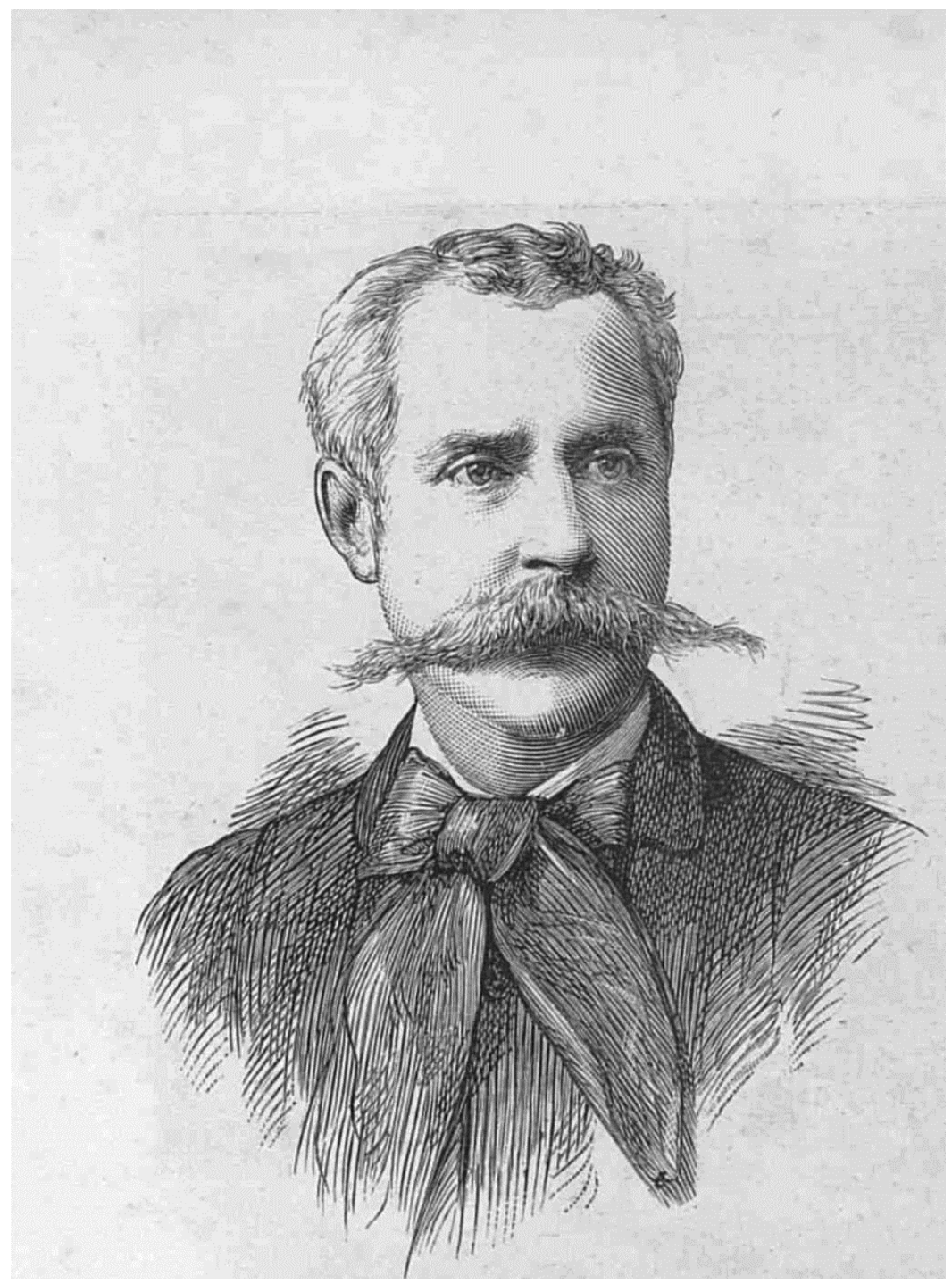

Appendix 1: Edgar Whitaker (1831-1903), Proprietor of The Levant Herald.

Photo: The Abdullah Frères 


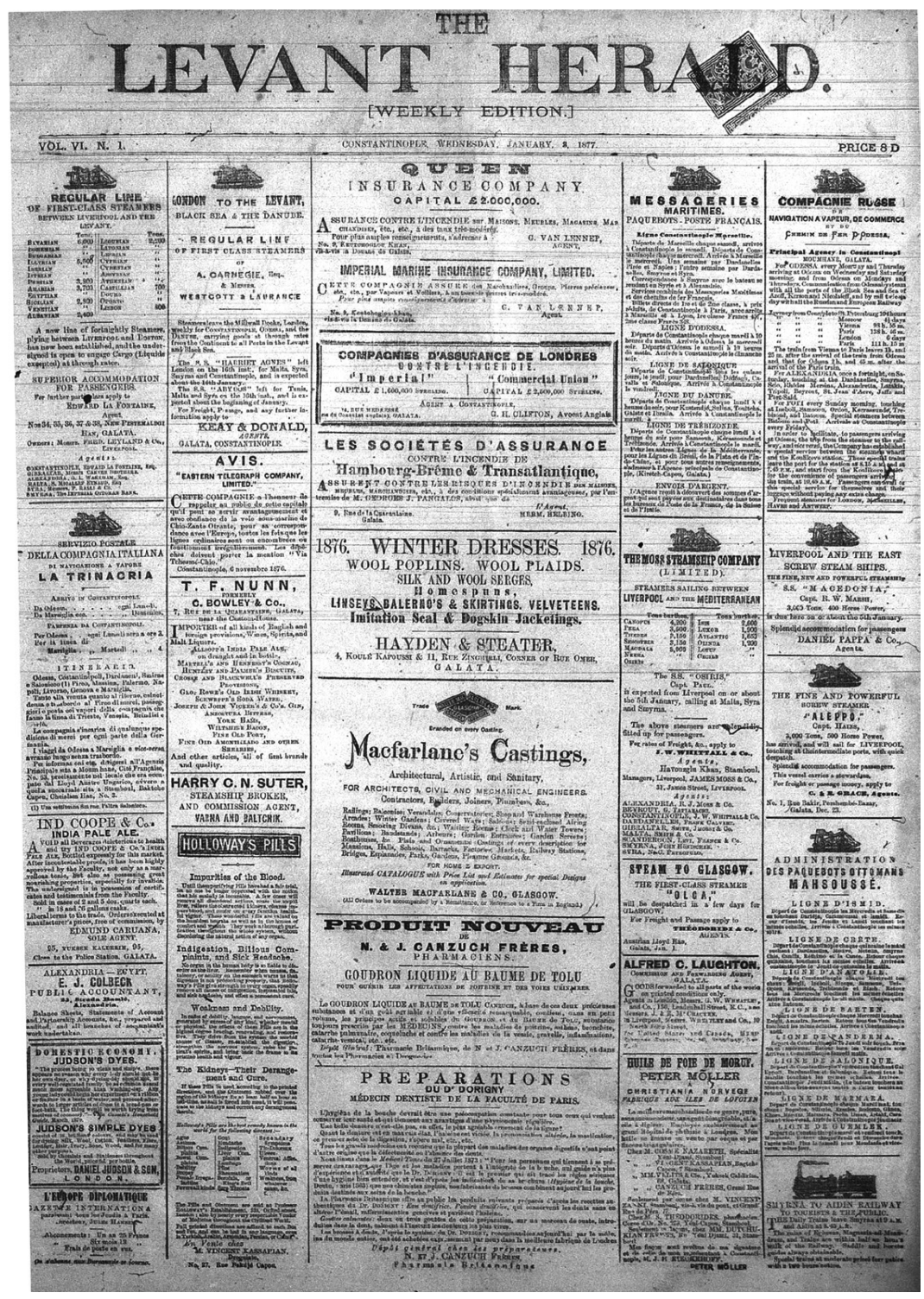

Appendix 2: The Levant Herald (Weekly Edition), January 8, 1877. 
